\title{
The detection, treatment, and biology of epithelial ovarian cancer
}

\author{
Jennifer AA Gubbels ${ }^{1}$, Nick Claussen ${ }^{2}$, Arvinder K Kapur ${ }^{2}$, Joseph P Connor ${ }^{2 *}$, Manish S Patankar ${ }^{2 *}$
}

\begin{abstract}
Ovarian cancer is particularly insidious in nature. Its ability to go undetected until late stages coupled with its nondescript signs and symptoms make it the seventh leading cause of cancer related deaths in women. Additionally, the lack of sensitive diagnostic tools and resistance to widely accepted chemotherapy regimens make ovarian cancer devastating to patients and families and frustrating to medical practitioners and researchers. Here, we provide an in-depth review of the theories describing the origin of ovarian cancer, molecular factors that influence its growth and development, and standard methods for detection and treatment. Special emphasis is focused on interactions between ovarian tumors and the innate and adaptive immune system and attempts that are currently underway to devise novel immunotherapeutic approaches for the treatment of ovarian tumors.
\end{abstract}

\section{Ovarian cancer occurrence}

Epithelial ovarian cancer (EOC) is the most deadly of gynecological cancers and is the seventh-leading cause of cancer deaths in women. In 2008, there were 21,650 cases reported which resulted in the deaths of 15,520 women in the United States [1]. Spread of the disease within the peritoneal cavity is associated with non-specific clinical symptoms that are often mistaken for other gastrointestinal or reproductive diseases. Some of the most common symptoms are abdominal discomfort and bloating. Other symptoms include vaginal bleeding, gastrointestinal discomfort, early satiety, and urinary tract symptoms [2]. Another obstacle hindering diagnosis is the fact that the ovaries are deep within the pelvic cavity and difficult to palpate, especially in peri-post menopausal women, the group with the highest incidence of the disease. Because of these reasons, $70 \%$ of patients are not diagnosed with the disease until the cancer has metastasized beyond the ovaries and is at stage III or IV [3]. However, studies surveying ovarian cancer patients demonstrate that over $95 \%$ of EOC patients had abdominal complaints for many months before their diagnosis [4-6]. There is now a new initiative to quantify the symptoms experienced by ovarian cancer patients prior to diagnosis of the disease. A "Symptoms Index" has been established and studies are underway to determine

\footnotetext{
*Correspondence: jpconnor@wisc.edu; patankar@wisc.edu

2Department of Obstetrics and Gynecology, University of Wisconsin-Madison, 600 Highland Ave, Madison, WI, 53792, USA
}

if it can be used- either independently or in combination- with a molecular marker as a predictor of early stage ovarian cancer $[5,6]$.

There are several different types of ovarian cancers depending upon the cell type of origin. Epithelial cell ovarian cancer (EOC) constitutes $90 \%$ of ovarian cancers, while gonadal-stromal ( $6 \%$ occurrence), and germ cell ( $4 \%$ occurrence) tumors make up the rest of the incidence of ovarian cancer patients [7]. As ovarian cancer of epithelial cell origin is the most common type, EOC is discussed throughout this review.

The majority of EOC cases are sporadic in nature and occur in women with no known predisposing factors and thus, in the general population, the overall risk of EOC is low (2-5\%). Only a small percentage $(5-10 \%)$ of EOC patients have a genetic predisposition to the disease. Ninety percent of these patients are carriers of mutated BRCA1 and/or BRCA2 genes, which are also implicated in hereditary breast cancer [8]. These genes normally act as tumor suppressors and regulate cellular proliferation and DNA repair by maintaining chromosome integrity. Mutations in these genes render the proteins unable to perform their intended functions. The lifetime risk of ovarian cancer for patients with BRCA1 mutations is $20 \%$ to $60 \%$, and the risk for BRCA2 mutation carriers is $10 \%$ to $35 \%$ [8]. Ovarian cancers associated with germline mutations of BRCA1 appear to be predominantly of serous type and age of the patient at diagnosis is significantly less as compared to the 
sporadic ovarian cancers $[9,10]$. Women who have this mutation may elect to undergo prophylactic bilateral salpingo-oophorectomy (removal of both fallopian tubes and ovaries).

\section{Origins of EOC}

The normal ovarian surface epithelium (OSE) covers the surface of the ovary. OSE is highly responsive to environmental stimuli, including those associated with ovulation [11]. In a normal woman, OSE are a monolayered squamous-to-cuboidal epithelium which functions to shuttle molecules in and out of the peritoneal cavity, as well as participates in the rupture and repair that accompanies every ovulation [12]. These cells are morphologically indistinct and histologically simple; therefore, it is difficult to understand how these cells can transform into tumors [13]. The OSE derive from the embryonic celomic epithelial cells which are a part of the mesoderm. The fallopian tube, uterus, and endocervix are derived from the Mullerian duct which is an invagination of the celomic epithelium. It is hypothesized that OSE cells retain the ability to differentiate into four major histological subtypes, which could explain the distinct histological EOC subtypes. There are four common sub-types of EOC including serous (fallopian tube-like), endometrioid (endometrium-like), mucinous (endocervical-like), and clear cell (mesonephros-like) [12].

The differentiation of OSE cells from cuboidal epithelial cells to a mesenchymal phenotype that is characteristic of Mullerian duct-derived tissues is termed epithelial- mesenchymal transition (EMT). The occurrence of EMT is postulated to aid cells in movement during embryo tissue generation, tissue regeneration after wounding, and is implicated in the development of cancer [14]. OSE cells normally undergo EMT to heal the wound that forms following ovulation. Uncommitted OSE cells normally express keratin, which is associated with an epithelial cell type [12]. However, these cells also constitutively express vimentin, $\mathrm{N}$-cadherin, and smooth muscle alpha-actin, all of which are associated with the mesenchymal phenotype [12]. OSE cells also produce several proteolytic enzymes (which help to degrade the epithelial cell wall during ovulation), as well as secrete collagen type III, characteristics that are also common to mesenchymal cells. OSE cells express low levels of the mucin MUC16 (CA125). Mullerian-duct derived tissues express high levels of MUC16 (CA125), as do ovarian tumors [15]. As we will discuss later, MUC16 (CA125) over expression in ovarian tumors is an important marker for progression and regression of EOC.

OSE cells undergo EMT transition after ovulation to remodel the extracellular matrix and repair the post-ovulatory wound that is generated during expulsion of the oocyte. Epithelial cells are characteristically polar and are bound together with molecules (such as E-cadherin) that facilitate cell-cell junctions. Conversely, the mesenchymal phenotype is that of motility and movement, as well as reduced polarity of a cell [16]. The transition of OSE to a mesenchymal phenotype aids in the ovulatory process because these converted cells have increased motility, altered proliferative responses, and the ability to remodel the extracellular matrix (ECM) [17]. TGF- $\beta$, EGF, and collagen are all present at the site of ovulatory rupture and can induce OSE EMT. OSE cells also undergo EMT in collagen matrices. It is a normal function of OSE to undergo EMT, therefore, cancer may represent unregulated EMT [14].

The expression of markers that are associated with those of Mullerian-duct derived tissue are found in inclusion cysts, which are the site of many neoplasms. OSE lining inclusion cysts express higher levels of EOC markers MUC16 (CA125) and CA19-9 and is two to three times more metaplastic in women with ovarian tumors compared to OSE in normal ovaries [18]. The hypothesis that EOC may derive from inclusion cysts is based upon the incessant ovulation theory, first proposed by Fathalla in 1971 [19]. This theory is based upon epidemiological data that reveals that women on birth control or who have been pregnant and/or breastfeeding have decreased risk of ovarian cancer. Fathalla suggested that wounds in the epithelium surrounding the ovary caused by ovulation month after month can cause increased inflammation and cell proliferation; thereby increasing the chance for cells to form neoplasms. Higher ovulatory activity is associated with an increased accumulation of inclusion cysts and invaginations of the OSE, which provide a hospitable environment for tumor cell growth [20]. This concept is supported by in vitro evidence in which ovarian surface epithelial cells from both rats and mice have been continuously cultured, mimicking the constant damage and repair that OSE undergo. In both species these in vitro cells spontaneously transformed into cancerous cells [21-23]. Another observation that supports the incessant ovulation hypothesis is that studies have repeatedly shown that oral contraceptive use (which prevents ovulation) reduces ovarian cancer risk [24].

An alternative hypothesis related to that of incessant ovulation is known as the gonadotropin hypothesis [25-27]. High levels of gonadotropins initiate each ovulation and persist immediately after menopause. These hormones stimulate the ovulation-like process involving the expression of cytokines and proteolytic enzymes within the surface epithelium. I nflammatory factors may lead to a loss of the basement membrane and the formation of inclusion cysts which can contribute to cell 
transformation into cancer [20]. One animal model (ewes) showed that oxidants released during ovulation caused DNA fragmentation and apoptosis in cells that were closest to the rupture, while milder DNA damage and the accumulation of p53 was shown in decreasing levels farther away from the rupture site [28].

Others hypothesize that ovarian tumors do not arise from OSE at all, but derive directly from the Mullerianduct tissues and migrate to the ovarian surface. Dubeau first proposed this hypothesis in 1999 [29]. According to Dubeau, the theory which suggests that OSE cells must first differentiate into Mullerian-duct type cells via metaplasia before becoming neoplastic contradicts our current understanding of cancer, which is that the cancerous cells are less differentiated than the cells they originate from [30]. He suggests that a more likely scenario is that EOC derives from Mullerian-duct derived tissues, and has several compelling observations to support this hypothesis. Ovarian tumor cells share many similar characteristics to the cells of the fallopian tubes, uterus, and endocervix, and do not share histological or protein expression profile with the OSE. Dubeau argues that the fimbrae of the fallopian tubes, which literally rub up against the surface of the ovary during ovulation and sometimes adhere to the surface of the ovary due to inflammation, are a prime site for the development of metaplasia. The cells from the fimbrae of the fallopian tubes have been shown to have developed pre-neoplastic changes in women who have undergone surgery for prophylactic removal of their fallopian tubes because of a mutation in BRCA1 [31-33].

In addition to histological changes found in the fimbrae of the fallopian tubes, mutations in the tumor suppressor gene p53 in the distal fimbrae of women with the $\mathrm{BRCA}^{+}$mutation have also been observed [34]. Christopher Crum's group found strong p53 staining in benign tissues from $\mathrm{BRCA}^{+}$women who underwent prophylactic salpingo-oophorectomies. This staining correlated with mutations in the p53 gene in these same cells. Because the p53 mutations were found predominantly in the distal fimbrae of the fallopian tubes (the cells that are in contact with the OSE), the location of this staining may reveal one mechanism by which ovarian tumors arise in $\mathrm{BRCA}^{+}$women [34]. In 2008, Crum's group correlated the p53 mutation in the fallopian tube fimbrae with lower parity and increased age at first childbirth, which links this marker to incessant ovulation [35]. A comparison of p53 mutations in ovarian inclusion cysts with p53 mutations in the fimbrae of fallopian tubes, again from women who were $\mathrm{BRCA}^{+}$ was conducted. The results revealed that p53 mutations were not present in any inclusion cysts that were examined, but were present in $38 \%$ of fimbrae of fallopian tubes from these women [36]. Another piece of evidence to support the argument that EOC arises from the fallopian tube is that several studies have shown that tumor cells clinically identical to ovarian cancer cells are found in the peritoneal environment in women years after their ovaries have been removed for reasons other than cancer [37-39].

Dubeau states that ovarian cancer is over-diagnosed, and many of these cancers actually arise from the fallopian tube or peritoneal cavity wall. The origin of ovarian tumors is of important consideration, not only for nomenclature reasons, but for women who have the BRCA 1 or BRCA 2 mutation and are undergoing prophylactic surgery and who want to preserve their fertility. If the origin of ovarian cancer is indeed not the ovary, then the ovaries need not be removed, and cryopreservation of oocytes for future use is not an issue [30].

\section{Ovarian cancer detection}

Attempts to find an accurate screening test for EOC have, to date, been unsuccessful. CA125 (MUC16), originally thought to be an indicator of ovarian cancer, is now known to be quite non-specific as well as to lack the sensitivity to detect stage I disease. Bast and coworkers showed in the 1980s that CA125 was expressed in the serum of the majority of patients with EOC, as well as patients with cancer of the endometrium, fallopian tube, and endocervix [40-44]. CA125 serum levels are elevated in $80 \%$ of advanced stage EOC patients; however, this marker can be elevated in a variety of benign conditions and other non-gynecologic malignancies. High concentrations are found in pancreatic, breast, bladder, liver, and lung cancers, as well as benign diseases such as diverticulitis, uterine fibroids, endometriosis, benign ovarian cyst, tubo-ovarian abscess, hyperstimulation syndrome, and ectopic pregnancies [42,45-48]. Elevated levels are also found in physiological conditions including both normal pregnancy and menstruation [49]. Furthermore, CA125 levels are elevated in less than half of the cases in early-stage ovarian cancers, underscoring the lack of sensitivity to diagnose curable disease. Therefore, CA125 is not used as a screening test, but mainly as a measure of disease progression, regression, and predictor of recurrence during treatment for EOC. CA125 levels measured over a period of time along with transvaginal sonography has been shown to increase sensitivity [50], however, the cost of transvaginal screening limits its use in the general population. CA125 itself is a repeating peptide epitope on the large molecular weight mucin, MUC16 [51-54]. This mucin is expressed at low levels by normal ovarian surface epithelium and is overexpressed by EOC tumor cells $[43,49]$. Tumor cells secrete MUC16 into the peritoneal fluid (PF) and from the abdominal cavity this 
mucin leaks into the blood stream and can then be detected via the CA125 serum assay.

Proteomic approaches are being utilized to identify molecular markers for ovarian cancer and mathematical models are being developed to identify specific patterns that are indicative of disease [55]. Other promising markers for ovarian cancer include human epididymis protein-4 (HE4), decoy receptor-3 (DcR3), osteopontin, mesothelin, spondin-2, SMRP, CA72-4, ERBB2, inhibin, activin, EGFR, and lysophosphatidic acid, [50,56-66]. Of these the most promising is HE4 which is expressed on ovarian tumor cells from some patients that do not express CA125. Indeed, studies have shown that the combined monitoring of serum levels of CA125 and HE4 is likely to significantly improve the sensitivity for detection of ovarian cancer in women with pelvic mass [67]. An important study published recently has concluded that a steady increase in the serum concentrations of CA125, HE4, and mesothelin can be detected in patients up to 1-3 years before a clinical diagnosis of ovarian cancer is made in patients [68].

\section{Ovarian cancer staging and treatment}

Ovarian cancer is a surgically staged disease, meaning that it is impossible to tell what the stage of the cancer is without examining the extent of the metastasis surgically. Metastasis of ovarian cancer spreads by direct extension to neighboring organs from the ovaries or by the sloughing of tumor cells into the peritoneal cavity. These individual or groups of exfoliated cells float in the fluid of the peritoneal cavity and can subsequently bind to the wall of the peritoneal cavity and form additional lesions. The tumor cells also commonly disseminate by lymphatic spread [69]. Proper surgical staging requires a complete inspection of the peritoneal cavity and its contents, as well as evaluation of the retroperitoneal spaces and lymph nodes. At the same time that the EOC patient is being evaluated for the stage of the disease, the surgeon also attempts to remove all visible tumors from within the peritoneal cavity. Additionally, the surgeon washes the peritoneal cavity several times with saline in order to remove as many tumor cells as possible. This procedure is termed cytoreductive surgery or tumor debulking [70].

The stages (I-IV) of ovarian cancer are determined by the extent of metastasis. Stage I EOC is confined to the ovaries whereas stage II affects other pelvic structures. In stage III, the disease has spread beyond the pelvis into the upper abdominal cavity or into the draining nodal beds irrespective of peritoneal based disease. Stage IV is defined as disease outside of the peritoneal cavity and most commonly includes parenchymal liver lesions or malignant pleural effusions. Patients with stage I disease most commonly undergo bilateral oophorectomy, hysterectomy, and surgical staging including peritoneal biopsies, omentectomy, and pelvic and aortic lymph node dissection. In select cases of younger patients who wish to preserve fertility, only the affected ovary may be removed and a hysterectomy would not be performed [70]. Chemotherapy treatment in early stage disease is dependent upon the grade of the tumor. It is recommended that patients with advanced stage (II, III or IV) EOC undergo cytoreductive surgery to remove all visible tumor whenever feasible, followed by platinum and taxane based chemotherapy [70]. Despite a high rate of initial remission, these patients have a high rate of recurrence (at least 50\%) and overall poor survival. Cancer diagnosed in early stages has a much higher 5-year survival rate (Stage I: >90\%, Stage II: $70-80 \%$ ) compared to cancer diagnosed in later stages (Stage III: 20-30\%, Stage IV: $<5 \%$ ) [70]. A major advance in the treatment of ovarian cancer has come from intraperitoneal administration of platinum and taxane agents instead of the more conventional intravenous delivery of these drugs [71-73]. Of the 654 randomized patients included in one trial, the median survival for patients receiving intraperitoneal cisplatin was 49 months compared to 41 months for the cohort receiving intravenous cisplatin [73]. Increased cytotoxicity remains a major hurdle curtailing the efficacy of intraperitoneal chemotherapy [74].

Treatment is made difficult for EOC patients because metastasis is acute and tumor cells exert immunosuppressive effects. The anatomical location of the ovaries within the peritoneal cavity facilitates metastasis because tumor cells can spread by sloughing off of the main tumor and binding to many organs in the vicinity, including the peritoneal cavity surfaces and the highly vascular omentum [75]. This complicates treatment in that it is technically impossible to remove all cancerous cells during cytoreductive surgery. The accumulation of peritoneal fluid in ovarian cancer patients also contributes to metastasis by aiding the flow of tumor cells within the peritoneal cavity. Peritoneal fluid contains secretions from the tumor cells that have now been shown to contain many factors which aid in the inhibition of the immune system in these patients [76-83]. Furthermore, ovarian tumors also acquire resistance to chemotherapy. Spheroids, or clumps of tumor cells (extremely common in the peritoneal fluid of EOC patients), have been shown to be more resistant to chemotherapy [84]. De novo and acquired chemoresistance combined with expression of immunosuppressive factors makes it difficult to effectively treat ovarian cancer $[85,86]$.

\section{Tumorigenesis and Metastasis}

Tumorigenesis requires several genetic alterations, either somatic or inherited, that confer a selective growth 
advantage to the neoplastic cell population. During tumor development, initial random genetic alterations result in a tumor cell population with a proliferative advantage. These tumor cells become the progenitors of a clonal population that eventually dominates the tumor mass. Tumor progression is analogous to Darwinian selection, with repeated mutations and subsequent dominance of the daughter cell population via expression of traits that confer a survival advantage [86].

A defining characteristic of a malignant epithelial tumor is invasion beyond the basement membrane into the surrounding stromal tissues. For example, in breast disease benign tumors such as fibrocystic lesions, sclerosis adenoma, and fibroadenoma are all characterized by disorganization of the normal epithelial architecture. However, no matter how extensive this disorganization may become, these benign lesions are always characterized by a continuous basement membrane that separates the neoplastic epithelium from the stroma [87]. Malignant tumors are characterized by their ability to invade through the basement membrane after which it is impossible to determine how many cells have escaped from the primary tumor and have established at metastatic sites [88]. Similar to malignant invasion some non-cancerous cells can physiologically invade basement membranes. Common examples of this include migration of immune cells during an inflammatory response, endothelial cells during an angiogenic response, and trophoblasts into the endometrial stroma and blood vessels to establish contact with the maternal circulation during placentation. The mechanisms used by these cells are thought to be very similar to those used by invading tumor cells $[88,89]$. The difference between these normal functions and the invasion associated with tumor cells is the lack of regulation seen in cancer. The mechanisms for the regulation of invasiveness are yet undetermined. Development of novel therapeutic agents towards these factors could help treat inflammatory, and angiogenesis disorders, as well as cancer formation [88].

Once a tumor is established metastasis may occur. While primary tumors are usually successfully eliminated by surgical or chemotherapeutic means, metastases are more difficult to detect and treat [89]. Metastases can cause death via paraneoplastic syndromes, interference with the normal functioning of an organ because of a growing lesion, or from complications related to treatment [89].

EOC was originally thought to be of the linear-clonal model of metastasis, which states that a late stage clone of the tumor acquires an additional genetic change that enables metastatic progression [90]. However, metastasis may not be the final stage of clonal evolution during tumor progression. Some cells seem to have derived from early stage clones in the primary tumor while others derive from later stage clones. This group supports a model in which primary ovarian cancers have a common clonal origin but become polyclonal with different clones at both early and late stages of genetic divergence acquiring the ability to progress to metastasis [90].

The complexity of metastasis increases when one considers that each cancer type typically metastasizes to different areas in the body. This is termed the "seed vs. soil" hypothesis which was first observed by Stephen Paget in 1889 [91]. Referring to the tumor cell as the seed and a potential metastatic site as the "soil," he stated, "When a plant goes to seed, the seeds are scattered in all different directions; but they can only live and grow if they land on congenial soil." He hypothesized that this theory could be used to predict metastatic locations for different cancers. Different selective pressures exist in different organs and the tumor cells must adapt to these environments. Some of these pressures include hypoxia, presence of reactive oxygen species, or lack of nutrients. Tumor cells must then alter their phenotype in order to exist in environments with different selective pressures [92].

In ovarian cancer, the "seed vs. soil" observation holds true as the most common sites of metastasis are within the peritoneal cavity. Mesothelial cells that express mesothelin line the walls of the peritoneal cavity as well as the organs within it. We and others have shown that MUC16, present on the surface of cancer cells, binds readily to mesothelin $[93,94]$. Recently, the binding site for MUC16 on mesothelin was characterized [95]. This interaction is just one of the many that make the "soil" of mesothelial cells within the peritoneal cavity an appropriate environment for ovarian cancer tumor cells.

In order to efficiently metastasize, tumor cells must first detach from the primary tumor by downregulating adhesive molecules, then later upregulate adhesive molecules to attach again to the target site epithelium. The initial step of detachment requires disruption of cell-cell adhesions, and this is facilitated by a loss of E-cadherin. E-cadherin is tethered to the actin cytoskeleton, which plays a primary role in supporting cell-to-cell adhesions. The disruption of the expression of E-cadherin can then lead to cells which can disseminate from the primary tumor. Loss of E-cadherin function is necessary but not sufficient for an epithelial to mesenchymal cell type transition [95]. Loss of E- cadherin has been seen in many types of cancers, such as breast, prostate, esophagus, stomach, colon, skin, kidney, lung, liver, and ovary $[96,97]$.

After detachment from the primary tumor site, the next step of metastasis is to effectively invade into neighboring tissues. Movement of the tumor cells through solid tissues requires the acquisition of phenotypes that allow cells to degrade the ECM and 
subsequently acquire forward propelling movements to invade into these tissues [92].

Next, the tumor cells migrate into the circulation, lymphatic system, or peritoneal space. In EOC, metastasis is facilitated by the clockwise flow of peritoneal fluid. The final steps of metastasis include arrest in the small blood vessels of a distant organ, extravasation into the surrounding tissue and proliferation at the secondary site [92].

\section{Immune Evasion}

Patients with EOC often experience several periods of remission and relapse of increasingly shortening periods until their tumors become resistant to chemotherapeutic treatment [98]. Additionally, as the stages of cancer progress, patients exhibit progressively deficient immune responses, which indicate that the tumor has developed mechanisms to subvert the immune response and suppress immune surveillance [99]. The importance of the role of the immune system in the control and elimination of EOC is evidenced by a study that correlated the 5 -year overall survival in EOC with the presence or absence of tumor-infiltrating lymphocytes (TIL) (38\% vs. $4.5 \%$, respectively) [100]. There are several studies which show that molecules from the tumor directly inhibit immune cells. We have now also demonstrated that MUC16 protects the ovarian tumor cells by sterically blocking the NK cells from forming immune synapses with the cancer cells [101]. High levels of shed MUC16 (sMUC16) are present in the PF of EOC patients and this mucin binds to NK cells within the PF [76]. MUC16 binds specifically to the inhibitory receptor, Siglec-9 on the surface of the NK cells (Belisle et al., paper submitted). Normally, NK cells in the peripheral blood of healthy subjects have the phenotype 90\% CD16 ${ }^{+}$and $10 \% \mathrm{CD} 16^{-}$. The $\mathrm{CD}^{+} 6^{+}$phenotype is associated with activation and cytotoxicity, while the $\mathrm{CD}^{-} 6^{-}$cells release cytokines and are not cytotoxic [102]. In the PF of EOC patients, however, this ratio shifts to $60 \%$ CD16 ${ }^{+}$and $40 \%$ CD16. Therefore, there are less cytotoxic cells in the PF compared to the peripheral blood [76].

Other immune cell subsets can also be affected by factors within peritoneal fluid. A study published in 2001 described a factor within PF that induced the loss of the $\mathrm{T}$ cell receptor (TcR)-associated signal transducing zetachain $(\mathrm{CD} 3 \zeta)$ [81]. They isolated this factor using column chromatography, gradient centrifugation, and mass spectrometry and found that it was a $14 \mathrm{kD}$ factor that operated at the mRNA level [81]. Webb and colleagues have shown that CD1d antigen presentation to NKT cells is inhibited by factors within the PF. This effect was dose dependent and CD1d specific [103]. Another study determined that supernatants from ovarian cancer cell lines inhibited $\mathrm{CD} 8^{+} \mathrm{T}$ cell proliferation and function, as well as the cells' ability to produce IFN- $\gamma$. IL-2R subunits $\gamma$ and $\beta$ (but not $\alpha$ ) were significantly suppressed as measured by flow cytometry [104]. Our group has also described the presence of Decoy Receptor 3 (DcR3) in the peritoneal cavity of women with advanced EOC and that this molecule functions as a potent inhibitor of Fas-ligand mediated apoptosis a common regulatory mechanism of the normal immune system [80].

Tumor cells also produce ligands that can bind to activating receptors on immune cells and thus downregulate the expression of these receptors. The ligands for activating receptor NKG2D are MHC class I-chainrelated proteins A and B (MICA/MICB) and the UL16binding proteins (ULBP-3) [105]. NKG2D ligands are not expressed on normal, healthy cells and therefore the expression of NKG2D ligands is correlated with malignant transformation. NKG2D receptor is expressed by all NK cells, $\mathrm{CD} 8^{+} \mathrm{T}$ cells, most NKT cells, and a subset of $\mathrm{CD} 4^{+} \mathrm{T}$ cells [105]. When NKG2D binds to its ligands, it induces the cytotoxic activation and proliferation of the immune cell. However, MICA and MICB can be cleaved from tumor cells by tumor-associated mellatoproteinases, which leads to soluble MICA and MICB that can downregulate the expression of NKG2D [106]. Wang and colleagues showed, using flow cytometry, that serum from prostate and ovarian cancer patients contained high levels of soluble MICs and correlated increased soluble MIC expression with decreased expression of NKG2D on T cells and a subset of NKT cells in these patients [107]. Another study used immunohistochemistry to determine that tumor from 82 ovarian cancer patients showed expression of MICA, MICB, and ULBP-2, while none of these molecules was expressed by normal ovarian epithelium [108]. Strong expression of ULBP-2 correlated with decreased infiltration of $\mathrm{T}$ cells and poor prognosis [108].

\section{Immunotherapy In EOC}

Most pre-clinical models of cancer immunotherapy indicate that such treatments work best in the setting of minimal volume, sub-clinical disease. Thus it is thought that patients with minimal residual disease who clinically appear to be in remission are ideal candidates for immunotherapeutic strategies. Immunotherapies may not be robust enough to eliminate the entire tumor when used alone, however; their use after surgery and chemotherapy may be useful to eliminate remaining sub-clinical tumor cells to prevent recurrence. The high rate of clinical response to therapy and the subsequent high rate of recurrence in EOC after primary treatment is evidence of a large number of women with sub-clinical disease at the completion of therapy. These patients may offer an excellent setting for immunotherapy. 
There are several immunotherapies that have been targeted to MUC16 as well as mesothelin. One such immunotherapy, oregovomab, is an immunoglobulin (Ig) I gG1k subclass murine monoclonal antibody that binds with high affinity to circulating CA125. This antibody complexes with CA125 and is taken up and processed by APCs (antigen presenting cells) [109,110]. Both a humoral and cellular response are produced, as demonstrated by the production of CA125 specific antibodies, T-helper cells, and CTLs in patients who received treatment $[109,111,112]$. Survival was increased in patients that mounted $\mathrm{T}$-cell responses against CA125, however, the most recent results from a phase III trial published in January of 2009 stated that monoimmunotherapy treatment with oregovomab resulted in no significant difference in outcome compared to placebo [111].

Antibodies, designated 3A5 and 11D10, against the tandem repeat sequence of MUC16 have been conjugated to the cytotoxic auristatin analogs monomethylauristatin F and monomethylauristatin E [113,114]. These drug-conjugated antibodies have been utilized as agents for chemotoxic immunotherapy resulting in an improved therapeutic index against MUC16-expressing OVCAR-3 tumors that were xenogenically grown in mice [113].

Abagovomab (ACA125) is an anti-idiotypic antibody against the MUC16 antibody OC125 and mimics the antigenic epitope of MUC16. It serves as a surrogate when given to patients. In phase I and II trials, patients that received abagovomab antibody developed anti-antiidiotypic antibodies (Ab3) and this correlated with increased survival $[115,116]$. Reinartz and colleagues developed a fusion protein of ACA125 with interleukin 6 in order to stimulate ACA125 specific B cells [117]. This resulted in increased levels of Ab3 in patients who received treatment.

Mesothelin is normally expressed by mesothelial cells that line the pleura, peritoneum, and pericardium. It is highly expressed by tumor cells associated with pancreatic, ovarian, and lung adenocarcinomas as well as malignant mesothelioma $[118,119]$. Its normal function is unknown and knockout mice show no abormalities [120]. However, we and others [93,94] have shown that it binds to MUC16, which facilitates the metastasis of ovarian cancer cells to the peritoneal cavity. Agents that would inhibit this interaction would be beneficial to prevent metastasis in EOC patients. A majority of patients with serous epithelial ovarian cancer show increased levels of serum mesothelin, making it a suitable target for immunotherapies, considering its relatively low expression in normal tissues [121]. SS1P is a recombinant immunotoxin consisting of an anti-mesothelin Fv linked to a Pseudomonas exotoxin that mediates cell killing. Phase I trials have been completed with SS1P and have shown anti-tumor activity in heavily treated patients [122]. Pre-clinical studies in animal models have shown that treatment with SS1P has an increased effect when combined with chemotherapy [123].

MORAb-009 is a high affinity chimeric monoclonal IgG1/ $\kappa$ with high affinity and specificity for mesothelin [124]. This antibody both induces ADCC (antibodydependent cellular cytotoxicity) against tumor cells that express mesothelin as well as blocks the MUC16/ mesothelin interaction $[124,125]$. Phase I trials with MORAb-009 are underway with 11 patients, 6 with mesothelioma, 3 with pancreatic cancer, and 2 with ovarian cancer. CRS-207 is another mesothelin cancer vaccine that utilizes Listeria monocytogenes as the vector. Pre-clinical studies have shown this vaccine to elicit $\mathrm{CD}^{+} / \mathrm{CD}^{+} \mathrm{T}$ cell mesothelin specific responses in mice and cynomolgus monkeys. A Phase I trial for CRS-207 is underway [123].

There are several other molecular candidates that are being investigated for immunotherapy against ovarian cancer. Incubation of immune cells with ovarian cancer cells lead to generation of antigen specific $\mathrm{T}$ cells against THP-1 and other peptide epitopes of ovarian cancer [126]. Other potential antigens for immunotherapy include p53, Her-2 and TPD52. Vaccination with Her-2 peptides along with measles virus fusion protein, a promiscuous $\mathrm{T}$ cell epitope causes increased antitumor immune responses [127]. Similarly, 66\% of mice developing responses against TPD52 expressing prostate tumors were free of the cancer 85 days after tumor inoculation and were also able to resist a subsequent tumor challenge [128]. The high expression of TPD52 by ovarian tumors provides hope that this strategy may also provide benefit to ovarian cancer patients.

Autoantibodies against p53 are present in ovarian cancer patients and their presence is associated with improved survival [129]. In a phase II clinical study, patients vaccinated against specific p53 peptides showed proliferation of p53 specific T cells [130]. These proliferating $\mathrm{T}$ cells were immune competent and produced high levels of IFN- $\gamma$. A subset of the patients $(2 / 20$; $10 \%)$ developing $\mathrm{p} 53$-specific $\mathrm{T}$ cells showed evidence of stable disease as compared to the remaining cohort with clinical and biochemical evidence of progressive disease. These data indicate that more research is required to produce effective immunotherapeutic approaches for the treatment of ovarian tumors.

\section{Conclusion}

Cytoreductive surgery followed by intense chemotherapy with platinum and taxol has become a standard approach for the treatment of EOC. Therapy is especially effective if the cancer is detected at early stage of progression. Future advances in the management and 
cure of EOC will depend on development of novel treatment modalities and diagnostic tests that can accurately detect early stage low volume tumors. While chemotherapeutic approaches have been important in the management of EOC, there is a growing sense in the field that additional supportive therapeutic approaches will be required for effective elimination of the cancer. The polyclonal nature of EOC ensures that therapeutic approaches may not eliminate the entire spectrum of cancer cells present in a patient. Combinatorial approaches that can result in direct cytotoxicity, prevent tumor angiogenesis, inhibit cancer metastasis, and also simultaneously increase the immunologic detection of tumors may be required to eliminate the polyclonal tumors. Such a holistic approach will require delineation of the molecular mechanisms that allow tumors to metastasize, promote angiogenesis, and to circumvent any effective immunological responses.

The combined treatment strategies will benefit from the development of diagnostic and screening tests. To date the "gold standard" for assessing the regression and recurrence of EOC is the serum CA125 (MUC16) assay. However, this assay is limited in its scope. Development of novel proteomics based approaches for the development of diagnostic tests hold great promise. However, even after intense research, successful development of a proteomics-based diagnostic test has remained elusive.

Overall, significant hurdles still remain in the effective diagnosis and treatment of EOC. The significant advances made in the molecular understanding of EOC, development of murine models and novel proteomicsbased technologies, and the use of immune-based treatment approaches are likely to provide novel opportunities for the effective management of EOC.

\section{Acknowledgements \\ Funding for this research was provided by grants from the Department of Defense (\#W81XWH-04-1-0102), Medical Education Research Council (MERC) of the University of Wisconsin-Madison, charitable donation from Jean McKenzie, and start-up funds from the Department of Obstetrics and Gynecology to MSP.}

\section{Author details}

'Department of Biology, Augustana College, 2001 S. Summit Ave, Sioux Falls, SD, 57197, USA. 'Department of Obstetrics and Gynecology, University of Wisconsin-Madison, 600 Highland Ave, Madison, WI, 53792, USA.

\section{Authors' contributions}

JAAG, JPC, and MSP did the majority of the writing of this manuscript. NC and AK contributed by writing specific sections of this manuscript. All authors have read and approved this manuscript.

\section{Competing interests}

The authors declare that they have no competing interests.

Received: 10 November 2009 Accepted: 29 March 2010 Published: 29 March 2010
References

1. Jemal A, Siegel R, Ward E, Hao Y, Xu J, Murray T, Thun MJ: Cancer statistics, 2008. CA Cancer J Clin 2008, 58:71-96.

2. Friedlander ML: Prognostic factors in ovarian cancer. Semin Oncol 1998 25:305-314.

3. Permuth-Wey J, Sellers T: Epidemiology of ovarian cancer. Methods Mol Biol 2009, 472:413-437.

4. Lowe KA, Andersen MR, Urban N, Paley P, Dresher CW, Goff BA: The temporal stability of the Symptom Index among women at high-risk for ovarian cancer. Gynecol Oncol 2009, 114:225-230.

5. Andersen MR, Goff BA, Lowe KA, Scholler N, Bergan L, Dresher CW, Paley P, Urban N: Combining a symptoms index with CA 125 to improve detection of ovarian cancer. Cancer 2008, 113:484-489.

6. Goff BA, Mandel LS, Drescher CW, Urban N, Gough S, Schurman KM Patras J, Mahony BS, Andersen MR: Development of an ovarian cancer symptom index: possibilities for earlier detection. Cancer 2007, 109:221-227

7. Holschneider C, Berek J: Ovarian cancer: epidemiology, biology, and prognostic factors. Semin Surg Oncol 19:3-10.

8. Antoniou A, Pharoah PD, Narod S, Risch HA, Eyfjord JE, Hopper JL, Loman N, Olsson H, Johannsson O, Borg A, Pasini B, Radice P, Manoukian S, Eccles DM, Tang N, Olah E, Anton-Culver H, Warner E, Lubinski J, Gronwald J, Gorski B, Tulinius H, Thorlacius S, Eerola H, Nevanlinna H, Syrjakoski K, Kallioniemi OP, Thompson D, Evans C, Peto J, et al: Average risks of breast and ovarian cancer associated with BRCA1 or BRCA2 mutations detected in case Series unselected for family history: a combined analysis of 22 studies. Am J Hum Genet 2003, 72:1117-1130.

9. Rubin SC, Benjamin I, Behbakht K, Takahashi H, Morgan MA, LiVolsi VA, Berchuck A, Muto MG, Garber JE, Weber BL, Lynch HT, Boyd J: Clinical and pathological features of ovarian cancer in women with germ-line mutations of BRCA1. N Engl J Med 1996, 335:1413-1416.

10. King MC, Marks JH, Mandell JB: Breast and ovarian cancer risks due to inherited mutations in BRCA1 and BRCA2. Science 2003, 302:643-646.

11. Kruk PA, Uitto VJ, Firth JD, Dedhar S, Auersperg N: Reciprocal interactions between human ovarian surface epithelial cells and adjacent extracellular matrix. Exp Cell Res 1994, 215:97-108.

12. Auersperg N, Wong AS, Choi KC, Kang SK, Leung PC: Ovarian surface epithelium: biology, endocrinology, and pathology. Endocr Rev 2001, 22:255-288.

13. Connolly DC, Bao R, Nikitin AY, Stephens KC, Poole TW, Hua X, Harris SS, Vanderhyden $\mathrm{BC}$, Hamilton TC: Female mice chimeric for expression of the simian virus $40 \mathrm{TAg}$ under control of the MISIIR promoter develop epithelial ovarian cancer. Cancer Res 2003, 63:1389-1397.

14. Ahmed N, Thompson E, Quinn M: Epithelial-mesenchymal interconversions in normal ovarian surface epithelium and ovarian carcinomas: an exception to the norm. J Cell Physiol 2007, 213:581-588.

15. Neunteufel W, Breitenecker G: Tissue expression of CA 125 in benign and malignant lesions of ovary and fallopian tube: a comparison with CA 199 and CEA. Gynecol Oncol 1989, 32:297-302.

16. Salamanca C, Maines-Bandiera S, Leung P, Hu Y, Auersperg N: Effects of epidermal growth factor/hydrocortisone on the growth and differentiation of human ovarian surface epithelium. J Soc Gynecol Investig 2004, 11:241-251

17. Ahmed N, Maines-Bandiera S, Quinn M, Unger W, Dedhar S, Auersperg N: Molecular pathways regulating EGF-induced epithelio-mesenchymal transition in human ovarian surface epithelium. Am J Physiol Cell Physiol 2006, 290:C1532-1542.

18. Scully R: Pathology of ovarian cancer precursors. J Cell Biochem Supp/ 1995, 23:208-218.

19. Fathalla MF: Incessant ovulation-a factor in ovarian neoplasia? Lancet 1971, 2:163.

20. Ozols RF, Bookman MA, Connolly DC, Daly MB, Godwin AK, Schilder RJ, Xu X, Hamilton TC: Focus on epithelial ovarian cancer. Cancer Cell 2004, 5:19-24.

21. Testa JR, Getts LA, Salazar H, Liu Z, Handel LM, Godwin AK, Hamilton TC Spontaneous transformation of rat ovarian surface epithelial cells results in well to poorly differentiated tumors with a parallel range of cytogenetic complexity. Cancer Res 1994, 54:2778-2784.

22. Godwin AK, Testa JR, Handel LM, Liu Z, Vanderveer LA, Tracey PA, Hamilton TC: Spontaneous transformation of rat ovarian surface epithelial cells: association with cytogenetic changes and implications of 
repeated ovulation in the etiology of ovarian cancer. $J$ Natl Cancer Inst 1992, 84:592-601.

23. Roby KF, Taylor CC, Sweetwood JP, Cheng Y, Pace JL, Tawfik O, Persons DL, Smith PG, Terranova PF: Development of a syngeneic mouse model for events related to ovarian cancer. Carcinogenesis 2000, 21:585-591.

24. Tworoger S, Fairfield K, Colditz G, Rosner B, Hankinson S: Association of oral contraceptive use, other contraceptive methods, and infertility with ovarian cancer risk. Am J Epidemiol 2007, 166:894-901.

25. Cramer DW, Hutchison GB, Welch WR, Scully RE, Ryan KJ: Determinants of ovarian cancer risk. I. Reproductive experiences and family history. J Nat Cancer Inst 1983, 71:711-716.

26. Cramer DW, Hutchison GB, Welch WR, Scully RE, Knapp RC: Factors affecting the association of oral contraceptives and ovarian cancer. $N$ Engl J Med 1982, 307:1047-1051.

27. Konishi I, Kuroda H, Mandai M: Review: gonadotropins and development of ovarian cancer. Oncology 1999, 57(Suppl 2):45-48

28. Murdoch W, Townsend R, McDonnel A: Ovulation-induced DNA damage in ovarian surface epithelial cells of ewes: prospective regulatory mechanisms of repair/survival and apoptosis. Biol Reprod 2001, 65:1417-1424.

29. Dubeau L: The cell of origin of ovarian epithelial tumors and the ovarian surface epithelium dogma: does the emperor have no clothes? Gynecol Oncol 1999, 72:437-442.

30. Dubeau L: The cell of origin of ovarian epithelial tumours. Lancet Oncol 2008, 9:1191-1197.

31. Callahan MJ, Crum CP, Medeiros F, Kindelberger DW, Elvin JA, Garber JE, Feltmate CM, Berkowitz RS, Muto MG: Primary fallopian tube malignancies in BRCA-positive women undergoing surgery for ovarian cancer risk reduction. J Clin Oncol 2007, 25:3985-3990.

32. Finch A, Beiner M, Lubinski J, Lynch HT, Moller P, Rosen B, Murphy J, Ghadirian P, Friedman E, Foulkes WD, Kim-Sing C, Wagner T, Tung N, Couch F, Stoppa-Lyonnet D, Ainsworth P, Daly M, Pasini B, GershoniBaruch R, Eng C, Olopade Ol, McLennan J, Karlan B, Weitzel J, Sun P, Narod SA: Salpingo-oophorectomy and the risk of ovarian, fallopian tube, and peritoneal cancers in women with a BRCA1 or BRCA2 Mutation. Jama 2006, 296:185-192.

33. Powell CB, Kenley E, Chen LM, Crawford B, McLennan J, Zaloudek C, Komaromy M, Beattie M, Ziegler J: Risk-reducing salpingo-oophorectomy in BRCA mutation carriers: role of serial sectioning in the detection of occult malignancy. J Clin Oncol 2005, 23:127-132.

34. Lee Y, Miron A, Drapkin R, Nucci MR, Medeiros F, Saleemuddin A, Garber J, Birch C, Mou H, Gordon RW, Cramer DW, McKeon FD, Crum CP: A candidate precursor to serous carcinoma that originates in the distal fallopian tube. J Pathol 2007, 211:26-35.

35. Saleemuddin A, Folkins A, Garrett L, Garber J, Muto M, Crum C, Tworoger S: Risk factors for a serous cancer precursor ("p53 signature") in women with inherited BRCA mutations. Gynecol Oncol 2008, 111:226-232.

36. Folkins AK, Jarboe EA, Saleemuddin A, Lee Y, Callahan MJ, Drapkin R, Garber JE, Muto MG, Tworoger S, Crum CP: A candidate precursor to pelvic serous cancer ( $\mathrm{p} 53$ signature) and its prevalence in ovaries and fallopian tubes from women with BRCA mutations. Gynecol Oncol 2008, 109:168-173.

37. Dalrymple JC, Bannatyne P, Russell P, Solomon HJ, Tattersall MH, Atkinson K, Carter J, Duval P, Elliott P, Friedlander M, et al: Extraovarian peritoneal serous papillary carcinoma. A clinicopathologic study of 31 cases. Cancer 1989, 64:110-115.

38. Finch A, Shaw P, Rosen B, Murphy J, Narod SA, Colgan TJ: Clinical and pathologic findings of prophylactic salpingo-oophorectomies in 159 BRCA1 and BRCA2 carriers. Gynecol Oncol 2006, 100:58-64.

39. Fromm GL, Gershenson DM, Silva EG: Papillary serous carcinoma of the peritoneum. Obstet Gynecol 1990, 75:89-95.

40. Davis HM, Zurawski VR Jr, Bast RC Jr, Klug TL: Characterization of the CA 125 antigen associated with human epithelial ovarian carcinomas. Cancer Res 1986, 46:6143-6148.

41. Bast RC Jr, Klug TL, Schaetzl E, Lavin P, Niloff JM, Greber TF, Zurawski VR Jr. Knapp RC: Monitoring human ovarian carcinoma with a combination of CA 125, CA 19-9, and carcinoembryonic antigen. Am J Obstet Gynecol 1984, 149:553-559.

42. Niloff JM, Klug TL, Schaetzl E, Zurawski VR Jr, Knapp RC, Bast RC Jr: Elevation of serum CA125 in carcinomas of the fallopian tube, endometrium, and endocervix. Am J Obstet Gynecol 1984, 148:1057-1058
43. Klug TL, Bast RC Jr, Niloff JM, Knapp RC, Zurawski VR Jr: Monoclonal antibody immunoradiometric assay for an antigenic determinant (CA 125) associated with human epithelial ovarian carcinomas. Cancer Res 1984, 44:1048-1053.

44. Bast RC Jr, Klug TL, St John E, Jenison E, Niloff JM, Lazarus H, Berkowitz RS, Leavitt T, Griffiths CT, Parker L, Zurawski VR Jr, Knapp RC: A radioimmunoassay using a monoclonal antibody to monitor the course of epithelial ovarian cancer. N Engl J Med 1983, 309:883-887.

45. Barbieri RL: CA-125 in patients with endometriosis. Fertil Steril 1986, 45:767-769.

46. Barbieri RL, Niloff JM, Bast RC Jr, Scaetzl E, Kistner RW, Knapp RC: Elevated serum concentrations of CA-125 in patients with advanced endometriosis. Fertil Steril 1986, 45:630-634.

47. Ismail MA, Rotmensch J, Mercer LJ, Block BS, Salti Gl, Holt JA: CA-125 in peritoneal fluid from patients with nonmalignant gynecologic disorders. J Reprod Med 1994, 39:510-512.

48. Kafali $\mathrm{H}$, Artuc $\mathrm{H}$, Demir N: Use of CA125 fluctuation during the menstrual cycle as a tool in the clinical diagnosis of endometriosis; a preliminary report. Eur J Obstet Gynecol Reprod Biol 2004, 116:85-88.

49. Niloff JM, Knapp RC, Schaetzl E, Reynolds C, Bast RC Jr: CA125 antigen levels in obstetric and gynecologic patients. Obstet Gynecol 1984, 64:703-707.

50. Bast RJ: Status of tumor markers in ovarian cancer screening. $J$ Clin Oncol 2003, 21:200s-205s.

51. O'Brien TJ, Beard JB, Underwood L, Shigemasa K: The CA 125 gene: a newly discovered extension of the glycosylated $\mathrm{N}$-terminal domain doubles the size of this extracellular superstructure. Tumour Biol 2002, 23:154-169.

52. O'Brien TJ, Beard JB, Underwood LJ, Dennis RA, Santin AD, York L: The CA 125 gene: an extracellular superstructure dominated by repeat sequences. Tumour Biol 2001, 22:348-366.

53. Yin BW, Dnistrian A, Lloyd KO: Ovarian cancer antigen CA125 is encoded by the MUC16 mucin gene. Int J Cancer 2002, 98:737-740.

54. Yin BW, Lloyd KO: Molecular cloning of the CA125 ovarian cancer antigen: identification as a new mucin, MUC16. J Biol Chem 2001, 276:27371-27375.

55. Bast RJ, Brewer M, Zou C, Hernandez M, Daley M, Ozols R, Lu K, Lu Z, Badgwell D, Mills G, Skates S, Zhang Z, Chan D, Lokshin A, Yu Y: Prevention and early detection of ovarian cancer: mission impossible? Recent Results Cancer Res 2007, 174:91-100.

56. Hellstrom I, Hellstrom KE: SMRP and HE4 as biomarkers for ovarian carcinoma when used alone and in combination with CA125 and/or each other. Adv Exp Med Biol 2008, 622:15-21.

57. Hellstrom I, Raycraft J, Hayden-Ledbetter M, Ledbetter JA, Schummer M, McIntosh M, Drescher C, Urban N, Hellstrom KE: The HE4 (WFDC2) protein is a biomarker for ovarian carcinoma. Cancer Res 2003, 63:3695-3700

58. Lu KH, Patterson AP, Wang L, Marquez RT, Atkinson EN, Baggerly KA, Ramoth LR, Rosen DG, Liu J, Hellstrom I, Smith D, Hartmann L, Fishman D, Berchuck A, Schmandt R, Whitaker R, Gershenson DM, Mills GB, Bast RC Jr: Selection of potential markers for epithelial ovarian cancer with gene expression arrays and recursive descent partition analysis. Clin Cancer Res 2004, 10:3291-3300.

59. Rosen DG, Wang L, Atkinson JN, Yu Y, Lu KH, Diamandis EP, Hellstrom I, Mok SC, Liu J, Bast RC Jr: Potential markers that complement expression of CA125 in epithelial ovarian cancer. Gynecol Oncol 2005, 99:267-277.

60. Simon I, Liu Y, Krall KL, Urban N, Wolfert RL, Kim NW, McIntosh MW: Evaluation of the novel serum markers B7-H4, Spondin 2, and DcR3 for diagnosis and early detection of ovarian cancer. Gynecol Oncol 2007, 106:112-118.

61. Negishi Y, Iwabuchi H, Sakunaga H, Sakamoto M, Okabe K, Sato H, Asano G: Serum and tissue measurements of CA72-4 in ovarian cancer patients. Gynecol Oncol 1993, 48:148-154.

62. Berchuck A, Rodriguez GC, Kamel A, Dodge RK, Soper JT, Clarke-Pearson DL, Bast RC Jr: Epidermal growth factor receptor expression in normal ovarian epithelium and ovarian cancer. I. Correlation of receptor expression with prognostic factors in patients with ovarian cancer. Am J Obstet Gynecol 1991, 164:669-674.

63. Berchuck A, Kamel A, Whitaker R, Kerns B, Olt G, Kinney R, Soper JT, Dodge R, Clarke-Pearson DL, Marks P, et al: Overexpression of HER-2/neu is associated with poor survival in advanced epithelial ovarian cancer. Cancer Res 1990, 50:4087-4091. 
64. Baron AT, Cora EM, Lafky JM, Boardman CH, Buenafe MC, Rademaker A, Liu D, Fishman DA, Podratz KC, Maihle NJ: Soluble epidermal growth factor receptor (sEGFR/sErbB1) as a potential risk, screening, and diagnostic serum biomarker of epithelial ovarian cancer. Cancer Epidemiol Biomarkers Prev 2003, 12:103-113.

65. Maihle NJ, Baron AT, Barrette BA, Boardman CH, Christensen TA, Cora EM, Faupel-Badger JM, Greenwood T, Juneja SC, Lafky JM, Lee H, Reiter JL, Podratz KC: EGF/ErbB receptor family in ovarian cancer. Cancer Treat Res 2002, 107:247-258

66. Mills GB, Eder A, Fang X, Hasegawa Y, Mao M, Lu Y, Tanyi J, Tabassam FH, Wiener J, Lapushin R, Yu S, Parrott JA, Compton T, Tribley W, Fishman D, Stack MS, Gaudette D, Jaffe R, Furui T, Aoki J, Erickson JR: Critical role of lysophospholipids in the pathophysiology, diagnosis, and management of ovarian cancer. Cancer Treat Res 2002, 107:259-283.

67. Moore RG, Brown AK, Miller MC, Skates S, Allard WJ, Verch T, Steinhoff M, Messerlian G, DiSilvestro P, Granai CO, Bast RC Jr: The use of multiple novel tumor biomarkers for the detection of ovarian carcinoma in patients with a pelvic mass. Gynecol Oncol 2008, 108:402-408.

68. Anderson GL, McIntosh M, Wu L, Barnett M, Goodman G, Thorpe JD, Bergan L, Thornquist MD, Scholler N, Kim N, O'Briant K, Drescher C, Urban N: Assessing lead time of selected ovarian cancer biomarkers: a nested case-control study. J Natl Cancer Inst 102:26-38.

69. Tsumura N, Sakuragi N, Hareyama H, Satoh C, Oikawa M, Yamada H, Yamamoto R, Okuyama K, Fujino T, Sagawa T, Fujimoto S: Distribution pattern and risk factors of pelvic and para-aortic lymph node metastasis in epithelial ovarian carcinoma. Int J Cancer 1998, 79:526-530.

70. Hoskins WJ, Perez CA, Young RC: Principles and Practice of Gynecologic Oncology Philadelphia: Limmincott-Raven Publishers 1997.

71. Armstrong DK, Bundy B, Wenzel L, Huang HQ, Baergen R, Lele S, Copeland $L$, Walker $J$, Burger RA: Intraperitoneal cisplatin and paclitaxel in ovarian cancer. N Engl J Med 2006, 354:34-43.

72. Markman M, Bundy BN, Alberts DS, Fowler JM, Clark-Pearson DL, Carson LF, Wadler S, Sickel J: Phase III trial of standard-dose intravenous cisplatin plus paclitaxel versus moderately high-dose carboplatin followed by intravenous paclitaxel and intraperitoneal cisplatin in small-volume stage III ovarian carcinoma: an intergroup study of the Gynecologic Oncology Group, Southwestern Oncology Group, and Eastern Cooperative Oncology Group. J Clin Oncol 2001, 19:1001-1007.

73. Alberts DS, Liu PY, Hannigan EV, O'Toole R, Williams SD, Young JA, Franklin EW, Clarke-Pearson DL, Malviya VK, DuBeshter B: Intraperitoneal cisplatin plus intravenous cyclophosphamide versus intravenous cisplatin plus intravenous cyclophosphamide for stage III ovarian cancer. N Engl J Med 1996, 335:1950-1955.

74. Robinson WR, Beyer J: Factors affecting the completion of intraperitoneal chemotherapy in women with ovarian cancer. Int J Gynecol Cancer 20:70-74.

75. Tan DS, Agarwal R, Kaye SB: Mechanisms of transcoelomic metastasis in ovarian cancer. Lancet Oncol 2006, 7:925-934.

76. Belisle JA, Gubbels JA, Raphael CA, Migneault M, Rancourt C, Connor JP, Patankar MS: Peritoneal natural killer cells from epithelial ovarian cancer patients show an altered phenotype and bind to the tumour marker MUC16 (CA125). Immunology 2007, 122(3):418-29.

77. Chen C, Zhang C, Zhuang G, Luo H, Su J, Yin P, Wang J: Decoy receptor 3 overexpression and immunologic tolerance in hepatocellular carcinoma (HCC) development. Cancer Invest 2008, 26:965-974.

78. Conejo-Garcia JR, Benencia F, Courreges MC, Gimotty PA, Khang E, Buckanovich RJ, Frauwirth KA, Zhang L, Katsaros D, Thompson CB, Levine B, Coukos G: Ovarian carcinoma expresses the NKG2D ligand Letal and promotes the survival and expansion of CD28- antitumor T cells. Cancer Res 2004, 64:2175-2182.

79. Conejo-Garcia JR, Benencia F, Courreges MC, Khang E, Zhang L, MohamedHadley A, Vinocur JM, Buckanovich RJ, Thompson CB, Levine B, Coukos G: Letal, A tumor-associated NKG2D immunoreceptor ligand, induces activation and expansion of effector immune cells. Cancer Biol Ther 2003, 2:446-451.

80. Connor JP, Felder M: Ascites from epithelial ovarian cancer contain high levels of functional decoy receptor 3 (DcR3) and is associated with platinum resistance. Gynecol Oncol 2008, 111:330-335.

81. Taylor D, Bender D, Gerçel-Taylor C, Stanson J, Whiteside T: Modulation of $\mathrm{TcR} / \mathrm{CD} 3$-zeta chain expression by a circulating factor derived from ovarian cancer patients. Br J Cancer 2001, 84:1624-1629.
82. Migone TS, Zhang J, Luo X, Zhuang L, Chen C, Hu B, Hong JS, Perry JW, Chen SF, Zhou JX, Cho YH, Ullrich S, Kanakaraj P, Carrell J, Boyd E, Olsen HS, Hu G, Pukac L, Liu D, Ni J, Kim S, Gentz R, Feng P, Moore PA, Ruben SM, Wei P: TL1A is a TNF-like ligand for DR3 and TR6/DcR3 and functions as a T cell costimulator. Immunity 2002, 16:479-492.

83. Li W, Zhang C, Chen C, Zhuang G: Correlation between expression of DcR3 on tumor cells and sensitivity to FasL. Cell Mol Immunol 2007, 4:455-460.

84. Shield K, Ackland M, Ahmed N, Rice G: Multicellular spheroids in ovarian cancer metastases: Biology and pathology. Gynecol Oncol 2009, 113(1):143-8

85. Agarwal R, Kaye SB: Ovarian cancer: strategies for overcoming resistance to chemotherapy. Nat Rev Cancer 2003, 3:502-516.

86. Chien JR, Aletti G, Bell DA, Keeney GL, Shridhar V, Hartmann LC: Molecular pathogenesis and therapeutic targets in epithelial ovarian cancer. J Cell Biochem 2007, 102:1117-1129.

87. Liotta L, Stetler-Stevenson W: Tumor invasion and metastasis: an imbalance of positive and negative regulation. Cancer Res 1991 51:5054s-5059s.

88. DeVita VTJ, Hellman S, Rosenberg SA: Cancer: Principles and Practice of Oncology lippincott Williams and Wilkins, 72004

89. Steeg P: Tumor metastasis: mechanistic insights and clinical challenges. Nat Med 2006, 12:895-904.

90. Khalique L, Ayhan A, Whittaker J, Singh N, Jacobs I, Gayther S, Ramus S: The clonal evolution of metastases from primary serous epithelial ovarian cancers. Int J Cancer 2009, 124(7):1579-86.

91. Paget S: The distribution of secondary growths in cancer of the breast. 1889. Cancer Metastasis Rev 1989, 8:98-101.

92. Hunter K, Crawford N, Alsarraj J: Mechanisms of metastasis. Breast Cancer Res 2008, 10(Suppl 1):S2.

93. Rump A, Morikawa Y, Tanaka M, Minami S, Umesaki N, Takeuchi M, Miyajima A: Binding of ovarian cancer antigen CA125/MUC16 to mesothelin mediates cell adhesion. J Biol Chem 2004, 279:9190-9198.

94. Gubbels JA, Belisle J, Onda M, Rancourt C, Migneault M, Ho M, Bera TK, Connor J, Sathyanarayana BK, Lee B, Pastan I, Patankar MS: MesothelinMUC16 binding is a high affinity, N-glycan dependent interaction that facilitates peritoneal metastasis of ovarian tumors. Mol Cancer 2006, 5:50.

95. Kaneko O, Gong L, Zhang J, Hansen J, Hassan R, Lee B, Ho M: A binding domain on mesothelin for CA125/MUC16. 2008, 284(6):3739-49.

96. Bracke ME, Van Roy FM, Mareel MM: The E-cadherin/catenin complex in invasion and metastasis. Curr Top Microbiol Immunol 1996, 213(Pt 1):123-161

97. Kuwabara Y, Yamada T, Yamazaki K, Du WL, Banno K, Aoki D, Sakamoto M: Establishment of an ovarian metastasis model and possible involvement of E-cadherin down-regulation in the metastasis. Cancer Sci 2008, 99:1933-1939.

98. Kajiyama H, Shibata K, Terauchi M, Yamashita M, Ino K, Nawa A, Kikkawa F: Chemoresistance to paclitaxel induces epithelial-mesenchymal transition and enhances metastatic potential for epithelial ovarian carcinoma cells. Int J Oncol 2007, 31:277-283.

99. Berek J, Bast RJ, Lichtenstein A, Hacker N, Spina C, Lagasse L, Knapp R, Zighelboim J: Lymphocyte cytotoxicity in the peritoneal cavity and blood of patients with ovarian cancer. Obstet Gynecol 1984, 64:708-714.

100. Zhang L, Conejo-Garcia JR, Katsaros D, Gimotty PA, Massobrio M, Regnani G, Makrigiannakis A, Gray H, Schlienger K, Liebman MN, Rubin SC, Coukos G: Intratumoral T cells, recurrence, and survival in epithelial ovarian cancer. N Engl J Med 2003, 348:203-213.

101. Gubbels JA, Felder M, Horibata S, Belisle JA, Kapur A, Holden H, Petrie S, Migneault M, Rancourt C, Connor JP, Patankar MS: MUC16 provides immune protection by inhibiting synapse formation between NK and ovarian tumor cells. Mol Cancer 9:11.

102. Cooper M, Caligiuri M: Isolation and characterization of human natural killer cell subsets. Curr Protoc Immunol 2004, Chapter 7(Unit 7.34).

103. Webb T, Giuntoli Rn, Rogers O, Schneck J, Oelke M: Ascites specific inhibition of CD1d-mediated activation of natural killer T cells. Clin Cancer Res 2008, 14:7652-7658.

104. Wang H, Xie X, Lu WG, Ye DF, Chen HZ, Li X, Cheng Q: Ovarian carcinoma cells inhibit T cell proliferation: suppression of IL-2 receptor beta and gamma expression and their JAK-STAT signaling pathway. Life Sci 2004, 74:1739-1749. 
105. Nausch N, Cerwenka A: NKG2D ligands in tumor immunity. Oncogene 2008, 27:5944-5958.

106. Groh V, Wu J, Yee C, Spies T: Tumour-derived soluble MIC ligands impair expression of NKG2D and T-cell activation. Nature 2002, 419:734-738.

107. Wang H, Yang D, Xu W, Wang Y, Ruan Z, Zhao T, Han J, Wu Y: Tumorderived soluble MICs impair CD3(+)CD56(+) NKT-like cell cytotoxicity in cancer patients. Immunol Lett 2008, 120:65-71.

108. Li K, Mandai M, Hamanishi J, Matsumura N, Suzuki A, Yagi H, Yamaguchi K, Baba T, Fujii S, Konishi I: Clinical significance of the NKG2D ligands, MICA/ $B$ and ULBP2 in ovarian cancer: high expression of ULBP2 is an indicator of poor prognosis. Cancer Immunol Immunother 2009, 58:641-652.

109. Noujaim AA, Schultes BC, Baum RP, Madiyalakan R: Induction of CA125specific $B$ and T cell responses in patients injected with MAb-B43.13evidence for antibody-mediated antigen-processing and presentation of CA125 in vivo. Cancer Biother Radiopharm 2001, 16:187-203.

110. Schultes BC, Zhang C, Xue LY, Noujaim AA, Madiyalakan R: Immunotherapy of human ovarian carcinoma with OvaRex MAb-B43.13 in a human-PBLSCID/BG mouse model. Hybridoma 1999, 18:47-55.

111. Berek J, Taylor P, McGuire W, Smith L, Schultes B, Nicodemus C: Oregovomab maintenance monoimmunotherapy does not improve outcomes in advanced ovarian cancer. J Clin Oncol 2009, 27:418-425.

112. Baum RP, Noujaim AA, Nanci A, Moebus V, Hertel A, Niesen A, Donnerstag B, Sykes T, Boniface G, Hor G: Clinical course of ovarian cancer patients under repeated stimulation of HAMA using MAb OC125 and B43.13. Hybridoma 1993, 12:583-589.

113. Chen Y, Clark S, Wong T, Chen Y, Chen Y, Dennis MS, Luis E, Zhong F, Bheddah S, Koeppen H, Gogineni A, Ross S, Polakis P, Mallet W: Armed antibodies targeting the mucin repeats of the ovarian cancer antigen, MUC16, are highly efficacious in animal tumor models. Cancer Res 2007, 67:4924-4932.

114. Junutula JR, Raab H, Clark S, Bhakta S, Leipold DD, Weir S, Chen Y, Simpson M, Tsai SP, Dennis MS, Lu Y, Meng YG, Ng C, Yang J, Lee CC, Duenas E, Gorrell J, Katta V, Kim A, McDorman K, Flagella K, Venook R, Ross S, Spencer SD, Lee Wong W, Lowman HB, Vandlen R, Sliwkowski MX, Scheller RH, Polakis $\mathrm{P}$, et al: Site-specific conjugation of a cytotoxic drug to an antibody improves the therapeutic index. Nat Biotechnol 2008, 26:925-932.

115. Pfisterer J, du Bois A, Sehouli J, Loibl S, Reinartz S, Reuss A, Canzler U, Belau A, Jackisch C, Kimmig R, Wollschlaeger K, Heilmann V, Hilpert F: The anti-idiotypic antibody abagovomab in patients with recurrent ovarian cancer. A phase I trial of the AGO-OVAR. Ann Oncol 2006, 17:1568-1577.

116. Sabbatini P, Dupont J, Aghajanian C, Derosa F, Poynor E, Anderson S, Hensley M, Livingston P, lasonos A, Spriggs D, McGuire W, Reinartz S, Schneider S, Grande C, Lele S, Rodabaugh K, Kepner J, Ferrone S, Odunsi K: Phase I study of abagovomab in patients with epithelial ovarian, fallopian tube, or primary peritoneal cancer. Clin Cancer Res 2006, 12:5503-5510.

117. Reinartz S, Hombach A, Kohler S, Schlebusch $H$, Wallwiener D, Abken $H$, Wagner U: Interleukin-6 fused to an anti-idiotype antibody in a vaccine increases the specific humoral immune response against CA125+ (MUC16) ovarian cancer. Cancer Res 2003, 63:3234-3240.

118. Hassan R, Remaley AT, Sampson ML, Zhang J, Cox DD, Pingpank J, Alexander R, Willingham M, Pastan I, Onda M: Detection and quantitation of serum mesothelin, a tumor marker for patients with mesothelioma and ovarian cancer. Clin Cancer Res 2006, 12:447-453.

119. Argani P, lacobuzio-Donahue C, Ryu B, Rosty C, Goggins M, Wilentz RE, Murugesan SR, Leach SD, Jaffee E, Yeo CJ, Cameron JL, Kern SE, Hruban RH: Mesothelin is overexpressed in the vast majority of ductal adenocarcinomas of the pancreas: identification of a new pancreatic cancer marker by serial analysis of gene expression (SAGE). Clin Cancer Res 2001, 7:3862-3868.

120. Bera TK, Pastan I: Mesothelin is not required for normal mouse development or reproduction. Mol Cell Biol 2000, 20:2902-2906.

121. Ho M, Hassan R, Zhang J, Wang QC, Onda M, Bera T, Pastan I: Humoral immune response to mesothelin in mesothelioma and ovarian cancer patients. Clin Cancer Res 2005, 11:3814-3820.

122. Hassan R, Broaddus V, Wilson S, Liewehr D, Zhang J: Anti-mesothelin immunotoxin SS1P in combination with gemcitabine results in increased activity against mesothelin-expressing tumor xenografts. Clin Cancer Res 2007, 13:7166-7171.
123. Hassan R, Ho M: Mesothelin targeted cancer immunotherapy. Eur J Cancer 2008, 44:46-53.

124. Hassan R, Ebel W, Routhier EL, Patel R, Kline JB, Zhang J, Chao Q, Jacob S, Turchin H, Gibbs L, Phillips MD, Mudali S, lacobuzio-Donahue C, Jaffee EM, Moreno M, Pastan I, Sass PM, Nicolaides NC, Grasso L: Preclinical evaluation of MORAb-009, a chimeric antibody targeting tumorassociated mesothelin. Cancer Immun 2007, 7:20.

125. Hassan R, Schweizer C, Lu KF, Schuler B, Remaley AT, Weil SC, Pastan I: Inhibition of mesothelin-CA-125 interaction in patients with mesothelioma by the anti-mesothelin monoclonal antibody MORAb-009: Implications for cancer therapy. Lung Cancer 2009.

126. Sinnathamby G, Lauer P, Zerfass J, Hanson B, Karabudak A, Krakover J, Secord AA, Clay TM, Morse MA, Dubensky TW Jr, Brockstedt DG, Philip R, Giedlin M: Priming and activation of human ovarian and breast cancerspecific CD8+ T cells by polyvalent Listeria monocytogenes-based vaccines. J Immunother 2009, 32:856-869.

127. Kaumaya PT, Foy KC, Garrett J, Rawale SV, Vicari D, Thurmond JM, Lamb T, Mani A, Kane Y, Balint CR, Chalupa D, Otterson GA, Shapiro CL, Fowler JM, Grever MR, Bekaii-Saab TS, Carson WE: Phase I active immunotherapy with combination of two chimeric, human epidermal growth factor receptor 2, B-cell epitopes fused to a promiscuous T-cell epitope in patients with metastatic and/or recurrent solid tumors. J Clin Oncol 2009, 27:5270-5277.

128. Lewis JD, Sullivan LA, Byrne JA, de Riese W, Bright RK: Memory and cellular immunity induced by a DNA vaccine encoding self antigen TPD52 administered with soluble GM-CSF. Cancer Immunol Immunother 2009, 58:1337-1349.

129. Goodell V, Salazar LG, Urban N, Drescher CW, Gray H, Swensen RE, Mclntosh MW, Disis ML: Antibody immunity to the p53 oncogenic protein is a prognostic indicator in ovarian cancer. J Clin Oncol 2006, 24:762-768.

130. Leffers N, Lambeck AJ, Gooden MJ, Hoogeboom BN, Wolf R, Hamming IE, Hepkema BG, Willemse PH, Molmans BH, Hollema H, Drijfhout JW, Sluiter WJ, Valentijn AR, Fathers LM, Oostendorp J, Zee van der AG, Melief CJ, Burg van der SH, Daemen T, Nijman HW: Immunization with a P53 synthetic long peptide vaccine induces P53-specific immune responses in ovarian cancer patients, a phase II trial. Int I Cancer 2009, 125:2104-2113.

doi:10.1186/1757-2215-3-8

Cite this article as: Gubbels et al:: The detection, treatment, and biology of epithelial ovarian cancer. Journal of Ovarian Research 2010 3:8.

\section{Submit your next manuscript to BioMed Central and take full advantage of:}

- Convenient online submission

- Thorough peer review

- No space constraints or color figure charges

- Immediate publication on acceptance

- Inclusion in PubMed, CAS, Scopus and Google Scholar

- Research which is freely available for redistribution

Submit your manuscript at www.biomedcentral.com/submit
C Biomed Central 